\title{
Rapid and Simple Method for Determination of Target Organic Acids in Wine Using HPLC-DAD Analysis
}

\author{
Violeta Ivanova-Petropulos ${ }^{1}$ (ID $\cdot$ Dragana Petruševa $^{1} \cdot$ Sasa Mitrev $^{1}$ \\ Received: 28 September 2019 / Accepted: 4 February 2020 / Published online: 15 February 2020 \\ (C) Springer Science+Business Media, LLC, part of Springer Nature 2020
}

\begin{abstract}
A high-performance liquid chromatography method coupled to diode array detector (HPLC-DAD) was validated and applied for determination of targeted organic acids (tartaric, malic, shikimic, lactic, citric, and succinic) in Chardonnay and Merlot wines. Simple sample preparation was carried out, including only wine dilution with water and filtration before injection to the HPLC system. Separation of the analytes was performed with isocratic elution on a Shimadzu Shim-pack GIST C18 column $(250 \mathrm{~mm} \times$ $4 \mathrm{~mm}$ I.D., $5 \mu \mathrm{m}$ particle size) with a mobile phase, an aqueous solution of $\mathrm{H}_{3} \mathrm{PO}_{4}$, with a concentration of $5 \cdot 10^{-3} \mathrm{~mol} / \mathrm{L}$ at $\mathrm{pH} 2.1$ and flow rate of $1 \mathrm{~mL} / \mathrm{min}$. Monitoring of the acids was performed at $210 \mathrm{~nm}$ wavelength. The method provides values for the linearity $\left(R^{2}>0.998\right)$, limits of detection $(0.00002$ to $0.0025 \mathrm{~g} / \mathrm{L})$ and quantification $(0.00006$ to $0.0085 \mathrm{~g} / \mathrm{L})$, precision $(\mathrm{RSD}<$ $10 \%$ ), accuracy (recovery range $94.8-108 \%$ ), repeatability (RSD values 2.53 to $7.19 \%$ for white wine and 1.96 to $9.5 \%$ for red wine), and reproducibility (RSD values 2.08 to $12.69 \%$ for white wine and 5.21 to $14.77 \%$ for red wine). All validation parameters are considered acceptable in characterization of organic acids in wine. The results obtained for the samples studied showed similar content of organic acids to those found for wines from other regions of the world. Principal component analysis (PCA) was applied to verify the applicability of the quality control of the wines and resulted in the correct separation of the samples according to the variety.
\end{abstract}

Keywords Organic acids $\cdot$ HPLC $\cdot$ Wine $\cdot$ Validation

\section{Introduction}

Organic acids are primary metabolites present in grapes and wine. Their profile and concentration are important parameters in relation to the processing of grape juices and wines and determination of their chemical composition (Coelho et al. 2018). Organic acids contribute to the acidity and sensory perception of wine, such as flavor, aroma, and color. Also, these compounds influence the $\mathrm{pH}$, microbiological, physical, and chemical stability as well as taste balance of this widely consumed beverage (Castiñeira et al. 2002; Esteves et al. 2004; Silva et al. 2015). Moreover, during the wine aging, organic acids are involved into reactions of esterification and hence, influence the development of the wine bouquet. Therefore, the content of organic acids should be monitored for quality control of the acidity evolution during the different

Violeta Ivanova-Petropulos violeta.ivanova@ugd.edu.mk

1 Faculty of Agriculture, University "Goce Delčev" - Štip, Krste Misirkov 10-A, Štip 2000, Republic of North Macedonia stages of winemaking, starting from the grape juices and maceration, continuing to the alcoholic fermentation and wine stabilization processes (Tašev et al. 2016).

The main organic acids in wine are tartaric, malic, lactic, citric, and succinic acids. Their content in wines ranges from 5.5 to $8.5 \mathrm{~g} / \mathrm{L}$, depending on the variety and climatic conditions during the year (Peres et al. 2009). The L isomer (+) of tartaric acid is present in high amounts and is the dominant organic acid in wines which plays significant role in maintaining the chemical stability of the wine, its color, and taste. In fact, the most of the acid taste of wine is due to this acid. The content of tartaric acid decreases during the fermentation as a result of precipitation in a form of tartaric crystals (Lelova et al. 2018). During the malolactic fermentation undertaken by the lactic acid bacteria, the content of malic acid decreases due to its conversion to lactic acid, which concentration increases. Citric acid also influences the acidity of wines, and it is an important component in biochemical and metabolic processes (e.g., Krebs cycle), inhibits the growth of yeasts, and therefore, frequently, it is used as an acidifying agent in food and beverages. Hence, an excessive amount of citric acid in wine indicates adulteration (Silva et al. 2015). Succinic acid is 
as a by-product of the metabolization of nitrogen by yeast cells during fermentation (Lelova et al. 2018). At high levels, it has bitter and salty taste. In addition, shikimic acid, which is considered a factor for determination of grape origin, is present at low concentrations in comparison with the other carboxylic acids, such as tartaric and malic acid. This acid does not have an important organoleptic effect in wine (Tessini et al. 2009).

Various instrumental separation techniques have been used to identify and quantify organic acids in grapes, juice, and wine, such as chromatography, electrophoresis, and spectrometry. High-performance liquid chromatography (HPLC) coupled to diode array detector (DAD) is commonly used for analysis of individual organic acids, since it has been proven as a precise and sensitive technique for that purpose (Tusseau and Benoit 1987; Schneider et al. 1987; KordišKrapež et al. 2001; Pereira et al. 2010; Tašev et al. 2016; Coelho et al. 2018). Moreover, capillary electrophoresis (CE) coupled to UV detection, in direct or indirect modes, has been shown to be faster and may be used in a broader analytical range. It has been applied for determination of organic acids in grapes and wines (Saavedra and Barbas 2003; Mato et al. 2007; Peres et al. 2009; Lelova et al. 2018) offering efficient resolution of the analytes. Recently, Fourier transform infrared (FT-IR) spectroscopy with partial least squares (PLS) was used for the determination of lactic, succinic, malic, tartaric, citric, and acetic acid in wines, vinegars, and spirits (Regmi et al. 2012), as well as mass spectrometry (Silva et al. 2015; Ivanova-Petropulos et al. 2018).

Limited data are available for organic acids in Macedonian wines. Until today, only one study on the analysis of organic acids in red and white wines with reversed phase highperformance liquid chromatography coupled with diode array detector (RP-HPLC-DAD), after solid-phase extraction, has been published (Tašev et al. 2016). In addition, capillary electrophoresis methods have been applied for analysis of organic acids in Macedonian red wines. Thus, optimized and validated CE method, hyphenated with conductivity detection (CD), has been applied for determination of organic acids (oxalate, tartrate, malate, malonate, pyruvate, succinate, acetate, citrate, and lactate) and inorganic anions (sulfate and phosphate) in red Macedonian wines, including Vranec, Cabernet Sauvignon, and Merlot wines from various geographic areas. Optimization and application of a CZE coupled to ESI/QTOFMS (CZE-ESI/QTOF-MS) technique have been performed for fast and simple determination of tartaric, citric, malic, lactic, succinic, and shikimic acids in red Vranec wines, applying a very simple sample preparation (wine dilution and filtration). In this study, we aimed to develop and optimize a rapid, simple, and accurate method with RP-HPLC for determination of target organic acids (tartaric, malic, shikimic, lactic, citric, and succinic) in red and white wines, applying simple sample preparation (wine dilution and filtration) and isocratic elution phase comprised of acidified ultrapure water. The quality validation parameters of method, such as LOD, LOQs, linearity, recovery, repeatability, and reproducibility, are presented.

\section{Materials and Methods}

\section{Chemicals and Reagents}

Standards of organic acids used in the study were as follows: tartaric acid (>98\%), L(-)-malic acid (>98\%), shikimic acid (>98\%), L(+)-lactic acid (>98\%), citric acid (>98\%), and succinic acid ( $>98 \%)$, as well as water (purity for LC/MS) and $\mathrm{H}_{3} \mathrm{PO}_{4}(85 \%, v / v)$ (purity for LC/MS), methanol (HPLC grade); all were supplied from Sigma-Aldrich (Steinheim, Germany). Sep-Pak C18 cartridges (silica-based octadecylbonded phase with strong hydrophobicity, appropriate for organic acids in beverages) for solid-phase extraction (Waters). All other chemicals used were of analytical grade.

\section{Wine Samples}

In total, 12 wines were produced and analyzed, including the six red Merlot wines and six Chardonnay white wines, originating from various geographic areas in Macedonia (Gradsko, Gevgelija, Demir Kapija, Kavadarci, Negotino, and Skopje). All samples were dry wines with residual sugar content lower than $5 \mathrm{~g} / \mathrm{L}$. In order to check the matrix effect, two wines were used: sweet sparkling wine, containing $18.4 \mathrm{~g} / \mathrm{L}$ reducing sugars and sweet aromatized wine, containing $120 \mathrm{~g} / \mathrm{L}$ reducing sugars.

\section{Red Winemaking}

Grapes from Vitais vinifera L., Merlot $(\sim 100 \mathrm{~kg})$ from each wine area were harvested at optimal maturity (range 20 and 23 ${ }^{\circ}$ Brix, harvest 2017) and transported to experimental winery, whereas they were processed separately in a same way. Grape processing was performed with a mechanical crusher/ destemmer, and grape mash was collected in a fermentation tank $(50 \mathrm{~L})$, obtaining in total six lots with grapes from the six wine areas. Sulfur dioxide $(50 \mathrm{mg} / \mathrm{L})$ in a form of $5 \%$ sulfurous acid was added in the grape mash in order to protect the enzymatic oxidation, followed with addition of a commercial pectolytic enzyme preparation (Vinozym Vintage, FCE, Lamothe Abiet, France). After 3-4 h, wines were inoculated with commercial Saccharomyces cerevisiae yeast (Vinalco, Bitola, Macedonia). Before application, the yeast was previously rehydrated in water $\left(20 \mathrm{~g} / \mathrm{hL}\right.$, at $35{ }^{\circ} \mathrm{C}$ for $\left.30 \mathrm{~min}\right)$, followed by the addition of nutrients (containing sterols, polyunsaturated fatty acids, vitamins, and minerals) in a dose of $45 \mathrm{~g} / \mathrm{hL}$ (Go-ferm protect, Lallemand, France) to improve 
yeast survival, particularly in difficult fermentation conditions.

After addition of $\mathrm{SO}_{2}$, yeast and pectolytic enzyme, grape mash was macerated for 8-10 days and during that period (alcoholic fermentation), "pumping over" was applied in all lots, two times a day. After the maceration period, wines were separated from the pomace by mechanical pressing and stabilized in an inox tanks $(50 \mathrm{~L})$ for period of 2 weeks for tartrate stabilization. During stabilization period, wines were inoculated with malolactic bacteria culture $(1 \mathrm{~g} / \mathrm{hL}$, Christian Hansen) in order to perform malolactic fermentation at controlled temperature of $20^{\circ} \mathrm{C}$. After stabilization period, wine was bottled and stored in a cellar at $8-12^{\circ} \mathrm{C}$ for 1 year before analysis.

\section{White Winemaking}

Grapes from Vitis vinifera L., Chardonnay $(\sim 100 \mathrm{~kg})$ cultivated in different wine areas, were harvested at $20-22{ }^{\circ}$ Brix (harvest 2017) and transported to experimental winery. Grapes were processed with mechanical crusher/destemmer, and immediately, sulfur dioxide $(100 \mathrm{mg} / \mathrm{L})$ in a form of $5 \%$ sulfurous acid was added into the grape mashes, obtaining six lots. After addition of $\mathrm{SO}_{2}$, grape mash was macerated for 3$4 \mathrm{~h}$ and then, must be separated from the pomace and collected in fermentation tanks $(50 \mathrm{~L})$, followed by addition of Saccharomyces cerevisiae yeast (Vinalco, Bitola, Macedonia) to start the fermentation. After finishing the fermentation, wines were treated with $1 \mathrm{~g} / \mathrm{L}$ bentonite and cold stabilized at $-4{ }^{\circ} \mathrm{C}$ for 2 weeks before bottling. Bottles were stored in a cellar, at temperature between 8 and $12{ }^{\circ} \mathrm{C}$ for 1 year before analysis.

\section{HPLC-DAD Analysis}

The instrumentation used for identification and quantification of organic acids in wine samples was an Shimadzu HPLC Nexera XR system (model CBM-20A) consisted of a binary pump (LC-20ADXR), degassing unit (DGU-20A5R), autosampler (SIL-20ACXR), column oven (CTO-20 AC), diode array detector (SPD-M20A), and communication bus module (CB-20A) (Shimadzu, Oregon, USA). The data processing was performed on the Shimadzu LabSolutions software (version 5.86). Separation of the analytes was performed with isocratic elution at room temperature on a Shimadzu Shim-pack GIST C18 column $(250 \mathrm{~mm} \times 4 \mathrm{~mm}$ I.D., $5 \mu \mathrm{m}$ particle size). The mobile phase was an aqueous solution of $\mathrm{H}_{3} \mathrm{PO}_{4}$, with a concentration of $5 \cdot 10^{-3} \mathrm{~mol} / \mathrm{L}$ at $\mathrm{pH} 2.1$, at a flow rate of $1 \mathrm{~mL} / \mathrm{min}$. Separation and quantification of the organic acids were monitored at $210 \mathrm{~nm}$ and the sample injection volume was $10 \mu l$. The total run time was $12 \mathrm{~min}$.
Before HPLC analysis, wines were diluted with water in ration 1:10 for red wines and 1:5 for white wines and filtrated with $0.2-\mu \mathrm{m}$ filter (Life Sciences PTFE).

\section{Calibration and Validation Parameters}

Stock solutions of standards of each organic acids (tartaric, malic, lactic, citric, and succinic) were prepared in water with a concentration of $1 \mathrm{~g} / \mathrm{L}$, except for shikimic acid $(100 \mathrm{mg} / \mathrm{L})$. For quantification purpose, five-point calibration curves were constructed in a range from 0.01 to $5 \mathrm{~g} / \mathrm{L}$ for malic, citric, and succinic acids, 0.1 to $10 \mathrm{~g} / \mathrm{L}$ for tartaric and lactic acids, 0.01 to $10 \mathrm{~g} / \mathrm{L}$ for lactic acid, and 0.1 to $100 \mathrm{mg} / \mathrm{L}$ for shikimic acid (Table 1). Each calibration point was measured three times. Under the optimized separating conditions, performance of the developed method was validated using linearity, limits of detection and quantification, precision, accuracy, recovery, repeatability, and reproducibility.

\section{Statistical Analysis}

Statistical treatment, including calculation of mean, relative standard deviation, and standard error were performed with the STATISTICA 6.0 software (Stat Soft Inc., USA). Principal component analysis (PCA) was employed to evaluate the possible grouping of the wines, using the XLSTAT Software, version 7.5.2, Addinsoft (Paris, France).

\section{Results and Discussion}

\section{HPLC Conditions and Validation of the Method}

The main objective of the present work was to develop a rapid and simple method based on the HPLC-DAD technique for fast separation and simultaneous determination of individual targeted organic acids: tartaric, malic, shikimic, lactic, citric, and succinic acid concentration in red and white wine samples. For the separation of the analytes, isocratic elution with the aqueous solution of phosphoric acid was applied as a mobile phase $(5 \mathrm{mM}$, at $\mathrm{pH} 2.1)$. The typical chromatograms monitored at wavelength of $210 \mathrm{~nm}$, for a mixture of the organic acid standards, for a Chardonnay wine sample (Ch4) (diluted with water, 1:5), and for Merlot wine (M2) (diluted with water, 1:10) are shown in Fig. 1.

In order to check the effect of the matrix on the separation of the analytes, two sweet wines, sweet sparkling wine, containing $18.4 \mathrm{~g} / \mathrm{L}$ reducing sugars and sweet aromatized wine containing $120 \mathrm{~g} / \mathrm{L}$ reducing sugars, were prepared by solidphase extraction with $\mathrm{C} 18$ Sep-Pak (Waters) cartridges, in order to extract the organic acids and separate them from the matrix. SPE was performed according to the procedure of Tašev et al. (2016). Comparing the chromatographic profiles 
Table 1 Linear regression data: range of determination, coefficients of the regression curves (slope and intercept), and coefficient of determination $R^{2}$, LOD, and LOQ

\begin{tabular}{|c|c|c|c|c|c|c|c|c|}
\hline No & Compounds & $\mathrm{t}_{r}(\min )$ & Range (g/L) & Slope & Intercept & $R^{2}$ & LOD $(\mathrm{g} / \mathrm{L})$ & LOQ $(g / L)$ \\
\hline 1 & Tartaric acid & 3.51 & $0.1-10$ & $865,980.9$ & $15,504.72$ & 0.9989 & 0.001 & 0.0034 \\
\hline 2 & Malic acid & 4.73 & $0.01-5$ & $452,048.1$ & 2550.82 & 0.9994 & 0.0005 & 0.0018 \\
\hline 3 & Shikimic acid & 5.07 & $0.0001-100$ & $27,289.4$ & $22,058.81$ & 0.9997 & 0.00002 & 0.00006 \\
\hline 4 & Lactic acid & 5.75 & $0.01-10$ & $257,828.1$ & 1267.87 & 0.9994 & 0.0005 & 0.0017 \\
\hline 5 & Citric acid & 10.25 & $0.01-5$ & $602,402.7$ & 1418.37 & 0.9993 & 0.00089 & 0.0029 \\
\hline 6 & Succinic acid & 11.30 & $0.01-5$ & $301,856.7$ & 1855.84 & 0.9994 & 0.0025 & 0.0085 \\
\hline
\end{tabular}

$\mathrm{t}_{r}$ retention time, $L O D$ limit of detection, $L O Q$ limit of quantification. The order of acids is in according to the retention time shown on Figs. 1 and 2

of sweet wines prepared by dilution and SPE, it was noticed that matrix effect did not influence on the separation of organic acids of interest when sweet diluted wine was injected into the HPLC. Moreover, the chromatographic profile of the sweet wine prepared by dilution was very similar to the chromatographic profile of the same wine, prepared with SPE (Fig. 2). The obtained chromatographic peaks of organic acids in diluted wines are sharp, symmetrical, and well-separated from the matrix components present in the wine probably due to the ability of the stationary phase to overcome the problems with interferences in matrix. Namely, we used HPLC column, Shim-pack GIST, which is packed with newly developed high-purity porous spherical silica, improving the analytical precision and tolerating a wide $\mathrm{pH}(1-10)$, so in the proposed method, SPE was not necessary to be performed. Moreover, the aim of the study was to develop a simple and fast method, and therefore, we decided to apply only dilution of the wine sample prior to HPLC in order to achieve faster analysis, concluding that the proposed method is suitable for dry and sweet wines.

The HPLC conditions provided a good separation of the individual organic acids, without elution of the peaks, in the complexes that is, in the wine samples using isocratic elution with a low-cost mobile phase and after a simple sample pretreatment, i.e., dilution and filtration, which is the advantage of this method. Since the method is simple and fast and does not require specific sample preparation with time-consuming, the suggested method can be applied for determination of organic acids in red and white wines (dry and sweet) to control the quality (this is especially important for citric acid quantitation because its content should be controlled before wine

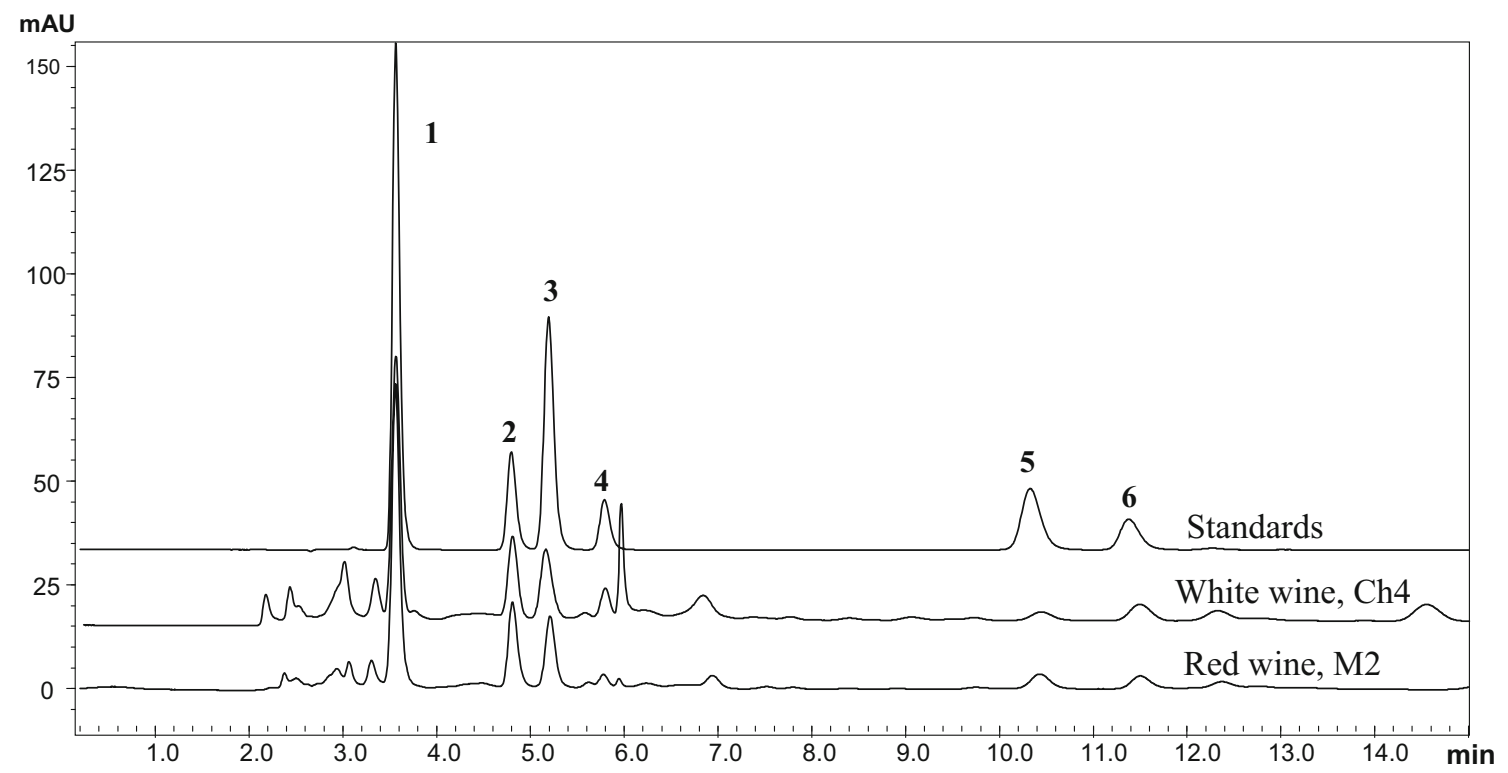

Fig. 1 HPLC-DAD separations of organic acids in standard solution, white wine, and red wine at wavelength of $210 \mathrm{~nm}$. Order of the analytes: (1) tartaric acid; (2) malic acid; (3) shikimic acid; (4) lactic acid; (5) citric acid; and (6) succinic acid. Experimental conditions: separation column Shimadzu Shim-pack GIST C18 column, room temperature, isocratic elution with aqueous solution of $\mathrm{H}_{3} \mathrm{PO}_{4}$, concentration $5 \cdot 10^{-3} \mathrm{~mol} / \mathrm{L}$, $\mathrm{pH} 2.1$, flow rate $1 \mathrm{~mL} / \mathrm{min}$, injection volume $10 \mu \mathrm{L}$, monitoring at $210 \mathrm{~nm}$ wavelength, and dilution of the samples (1:5 for white wine; 1:10 for red wine) 
Fig. 2 Comparison of UV-Vis chromatographic profiles of organic acids in sweet wine prepared by different sample preparation treatments: (A) dilution and filtration of the sample and (B) solid-phase extraction of the sample with C-18 Sep-Pak cartridges. Order of the analytes: (1) tartaric acid; (2) malic acid; (3) shikimic acid; (4) lactic acid; (5) citric acid; and (6) succinic acid. Experimental conditions: separation column Shimadzu Shim-pack GIST C18 column, room temperature, isocratic elution with aqueous solution of $\mathrm{H}_{3} \mathrm{PO}_{4}$, concentration $5 \cdot 10^{-3} \mathrm{~mol} / \mathrm{L}$, pH 2.1, flow rate $1 \mathrm{~mL} / \mathrm{min}$, injection volume $10 \mu \mathrm{L}$, and monitoring at $210 \mathrm{~nm}$ wavelength



export and/or wine import). Thus, this method will be very useful in scientific purposes, and it will be helpful for the wineries for controlling and improving the winemaking fermentation process.

The main parameters of the proposed HPLC-DAD method were thoroughly evaluated. The validation parameters, obtained from assays with standard solutions, blank samples, spiked samples, and wine samples were as follows: the calibration curve linearity, limits of detection (LOD) and quantification (LOQ), precision, accuracy, recovery, repeatability, and reproducibility.

\section{Linearity}

The range of linearity was established by injecting five different concentrations obtained by the dilution of a standard mixture of organic acids in ultrapure water. Analytical curves for each organic acid were obtained considering the correlation between the peak area and the respective concentration of the standard using a linear least square model. Linearity was tested in 3 days at five concentration levels. The linearity data, including slope, intercept, and correlation coefficient $\left(R^{2}\right)$ were calculated and they are presented in Table 1. As it can be seen from the table, the linearity is satisfactory in all cases with correlation coefficients $\left(R^{2}>0.998\right)$ ranging from 0.9989 for tartaric acid to 0.9997 for shikimic acid. $R$ values for the calibration curves higher than 0.99 verify that the linearity is adequate for the intended purpose.

\section{Limits of Detection (LOD) and Quantification (LOQ)}

The LOD and LOQ are used to demonstrate the ability of a method to detect and quantify a low concentration of an appropriate substance, respectively (Coelho et al. 2018). LOD was determined as a concentration of the analyte that gives a signal equal to the average background $\left(S_{\text {blank }}\right)$ plus three

Table 2 Precision of the proposed method

\begin{tabular}{|c|c|c|c|c|c|}
\hline \multirow[t]{3}{*}{ No } & \multirow[t]{3}{*}{ Compound } & \multicolumn{2}{|c|}{ Intra-day precision } & \multicolumn{2}{|c|}{ Inter-day precision } \\
\hline & & \multicolumn{2}{|c|}{$(R S D$ of peak area $\%, n=3)$} & \multicolumn{2}{|c|}{$(R S D$ of peak area $\%, n=9)$} \\
\hline & & Low level & High level & Low level & High level \\
\hline 1 & Tartaric acid & 0.38 & 0.11 & 0.39 & 0.47 \\
\hline 2 & Malic acid & 4.31 & 5.86 & 0.25 & 0.32 \\
\hline 3 & Shikimic acid & 0.57 & 0.80 & 0.17 & 0.11 \\
\hline 4 & Lactic acid & 4.15 & 3.44 & 0.24 & 0.34 \\
\hline 5 & Citric acid & 6.42 & 9.07 & 0.03 & 0.04 \\
\hline 6 & Succinic acid & 0.11 & 9.31 & 0.25 & 0.31 \\
\hline
\end{tabular}


Table 3 Standard additions for checking the accuracy of the HPLC-DAD method for determination of organic acids in wine samples $(n=3)$

\begin{tabular}{|c|c|c|c|c|c|c|c|c|c|c|c|c|c|}
\hline \multicolumn{2}{|l|}{ Compounds } & \multicolumn{2}{|c|}{ Tartaric acid $(\mathrm{g} / \mathrm{L})$} & \multicolumn{2}{|c|}{$\begin{array}{l}\text { Malic acid } \\
(\mathrm{g} / \mathrm{L})\end{array}$} & \multicolumn{2}{|c|}{$\begin{array}{l}\text { Shikimic acid } \\
(\mathrm{mg} / \mathrm{L})\end{array}$} & \multicolumn{2}{|c|}{$\begin{array}{l}\text { Lactic acid } \\
(\mathrm{g} / \mathrm{L})\end{array}$} & \multicolumn{2}{|c|}{$\begin{array}{l}\text { Citric acid } \\
(g / L)\end{array}$} & \multicolumn{2}{|c|}{$\begin{array}{l}\text { Succinic acid } \\
(\mathrm{g} / \mathrm{L})\end{array}$} \\
\hline Wine & & $\begin{array}{l}\text { White } \\
\text { wine }\end{array}$ & $\begin{array}{l}\text { Red } \\
\text { wine }\end{array}$ & $\begin{array}{l}\text { White } \\
\text { wine }\end{array}$ & $\begin{array}{l}\text { Red } \\
\text { wine }\end{array}$ & $\begin{array}{l}\text { White } \\
\text { wine }\end{array}$ & $\begin{array}{l}\text { Red } \\
\text { wine }\end{array}$ & $\begin{array}{l}\text { White } \\
\text { wine }\end{array}$ & $\begin{array}{l}\text { Red } \\
\text { wine }\end{array}$ & $\begin{array}{l}\text { White } \\
\text { wine }\end{array}$ & $\begin{array}{l}\text { Red } \\
\text { wine }\end{array}$ & $\begin{array}{l}\text { White } \\
\text { wine }\end{array}$ & $\begin{array}{l}\text { Red } \\
\text { wine }\end{array}$ \\
\hline \multirow[t]{3}{*}{ I. Conc. level } & Calculated (g/L) & 2.61 & 2.99 & 1.68 & 1.19 & 20.89 & 29.11 & 0.43 & 0.99 & 0.39 & 1.26 & 0.72 & 1.16 \\
\hline & Found $(\mathrm{g} / \mathrm{L})$ & 2.55 & 2.89 & 1.66 & 1.13 & 21.04 & 31.44 & 0.42 & 0.98 & 0.41 & 1.29 & 0.69 & 1.15 \\
\hline & Recovery (\%) & 97.75 & 96.73 & 98.57 & 94.80 & 100.7 & 108.0 & 97.62 & 98.77 & 105.3 & 102.5 & 95.66 & 98.76 \\
\hline \multirow[t]{3}{*}{ II. Conc. level } & Calculated (g/L) & 2.58 & 3.66 & 1.46 & 1.46 & 30.60 & 52.74 & 0.62 & 1.32 & 0.60 & 2.18 & 0.82 & 1.44 \\
\hline & Found $(\mathrm{g} / \mathrm{L})$ & 2.53 & 3.56 & 1.42 & 1.39 & 30.17 & 54.15 & 0.59 & 1.33 & 0.62 & 2.22 & 0.80 & 1.41 \\
\hline & Recovery (\%) & 98.28 & 97.15 & 97.46 & 95.38 & 98.60 & 102.7 & 94.93 & 100.6 & 103.4 & 101.9 & 97.77 & 97.64 \\
\hline \multirow[t]{3}{*}{ III. Conc. level } & Calculated (g/L) & 2.54 & 4.33 & 1.23 & 1.73 & 40.30 & 76.37 & 0.81 & 1.66 & 0.80 & 3.09 & 0.91 & 1.72 \\
\hline & Found $(\mathrm{g} / \mathrm{L})$ & 2.55 & 4.37 & 1.22 & 1.69 & 40.16 & 76.86 & 0.80 & 1.69 & 0.83 & 3.00 & 0.90 & 1.71 \\
\hline & Recovery (\%) & 100.6 & 100.8 & 99.18 & 97.46 & 99.66 & 100.6 & 98.21 & 101.4 & 104.2 & 97.21 & 99.33 & 99.63 \\
\hline
\end{tabular}

Wine samples, white wine (Ch4) and red wine (M2)

times of the standard deviation of the blank $\left(s_{\text {blank }}\right)$ than LOD $=\left(S_{\text {blank }}+3 \times s_{\text {blank }}\right.$-intercept $) /$ slope. The calculated intercept was used for estimation of $S_{\text {blank }}$, the blank signal itself. Standard deviation of blank $\left(s_{\text {blank }}\right)$ was expressed by random errors in the $\mathrm{y}$-direction of regression lines $\left(s_{\mathrm{y} / \mathrm{x}}\right)$, $\mathrm{LOD}=\left(3 s_{\mathrm{y} / \mathrm{x}}\right) /$ slope. $\mathrm{LOQ}$ was determined as $\mathrm{LOQ}=3 \times$ LOD. The obtained values for LOD and LOQ were determined in the low concentration calibration region and ranged from 0.00002 to $0.0025 \mathrm{~g} / \mathrm{L}$ and from 0.00006 to $0.0085 \mathrm{~g} / \mathrm{L}$, respectively (Table 1). Compared with the values found in the literature (Tašev et al. 2016; Coelho et al. 2018), our LOD and LOQ values were lower and were considered suitable for the use of this HPLC method for analysis of organic acids in red and white wine.

\section{Precision}

The intra-day and inter-day precision were determined by injection of standard solution with low concentration $(0.1 \mathrm{mg} / \mathrm{L}$ for tartaric acid, $0.01 \mathrm{~g} / \mathrm{L}$ for malic, lactic, citric, and succinic acids and $1 \mathrm{mg} / \mathrm{L}$ for shikimic acid) and high concentration ( $1 \mathrm{~g} / \mathrm{L}$ for tartaric acid, $0.5 \mathrm{~g} / \mathrm{L}$ for malic, lactic, citric, and succinic acids and $20 \mathrm{mg} / \mathrm{L}$ for shikimic acid) of tested analytes. For determination of intra-day precision, freshly prepared solutions were analyzed immediately after preparation, in 3 repetitions. The RSD values of peak areas for each analytes were lower than $10 \%$ for the low and for the high concentrations of all acids, which confirmed that the proposed method is precise (RSD range 0.11 to $9.07 \%$ ). Inter-day precision was determined during 3 consecutive days with three repeated analyses of daily prepared solutions. The intra-day precision (RSDs of peak areas) was better than $1 \%$. The other results are presented in Table 2.

The accuracy parameter was expressed with the recovery of the determined concentration compared with the true (nominal) value. It was checked using the standard addition method on real wine samples, one white wine (Ch4), and one red wine (M2). Wine samples were spiked at three

Table 4 Repeatability and reproducibility data

\begin{tabular}{|c|c|c|c|c|c|c|c|c|c|}
\hline \multirow[t]{3}{*}{ No } & \multirow[t]{3}{*}{ Compound } & \multicolumn{4}{|c|}{ Repeatability (6 replicates) } & \multicolumn{4}{|c|}{ Reproducibility ( 3 replicates $\times 5$ days) } \\
\hline & & \multicolumn{2}{|l|}{ White wine } & \multicolumn{2}{|l|}{ Red wine } & \multicolumn{2}{|l|}{ White wine } & \multicolumn{2}{|l|}{ Red wine } \\
\hline & & $\begin{array}{l}\text { Mean } \\
\text { concentration }\end{array}$ & $\begin{array}{l}\text { RSD } \\
(\%)\end{array}$ & $\begin{array}{l}\text { Mean } \\
\text { concentration }\end{array}$ & $\begin{array}{l}\text { RSD } \\
(\%)\end{array}$ & $\begin{array}{l}\text { Mean } \\
\text { concentration }\end{array}$ & $\begin{array}{l}\text { RSD } \\
(\%)\end{array}$ & $\begin{array}{l}\text { Mean } \\
\text { concentration }\end{array}$ & $\begin{array}{l}\text { RSD } \\
(\%)\end{array}$ \\
\hline 1 & Tartaric acid $(\mathrm{g} / \mathrm{L})$ & 2.63 & 3.26 & 2.04 & 5.29 & 2.57 & 2.40 & 2.09 & 4.47 \\
\hline 2 & Malic acid $(g / L)$ & 1.87 & 3.39 & 0.53 & 9.50 & 2.01 & 12.69 & 0.56 & 9.71 \\
\hline 3 & Shikimic acid $(\mathrm{mg} / \mathrm{L})$ & 10.24 & 6.62 & 8.77 & 5.65 & 10.66 & 5.94 & 9.44 & 9.99 \\
\hline 4 & Lactic acid $(\mathrm{g} / \mathrm{L})$ & 0.12 & 2.53 & 0.60 & 1.96 & 0.12 & 8.14 & 0.61 & 2.35 \\
\hline 5 & Citric acid $(g / L)$ & 0.19 & 4.73 & 0.50 & 8.98 & 0.19 & 2.08 & 0.47 & 14.77 \\
\hline 6 & Succinic acid (g/L) & 0.61 & 7.19 & 0.85 & 3.61 & 0.61 & 7.13 & 0.82 & 5.21 \\
\hline
\end{tabular}

Wine samples, Ch4 (white wine) and M2 (red wine) 
Table 5 Content of organic acids $(\mathrm{g} / \mathrm{L})$ in Chardonnay and Merlot wines produced from different wine regions

\begin{tabular}{|c|c|c|c|c|c|c|c|c|}
\hline No & Wines & Tartaric acid $(\mathrm{g} / \mathrm{L})$ & Malic acid (g/L) & Shikimic acid $(\mathrm{g} / \mathrm{L})$ & Lactic acid $(\mathrm{g} / \mathrm{L})$ & Citric acid (g/L) & Succinic acid (g/L) & $\Sigma(\mathrm{g} / \mathrm{L})$ \\
\hline 1 & M 1 & $2.85 \pm 0.02$ & $0.17 \pm 0.01$ & $10.85 \pm 0.75$ & $1.30 \pm 0.04$ & $0.28 \pm 0.1$ & $0.74 \pm 0.04$ & 5.35 \\
\hline 2 & M 2 & $1.98 \pm 0.10$ & $0.57 \pm 0.07$ & $9.54 \pm 1.73$ & $0.64 \pm 0.02$ & $0.19 \pm 0.02$ & $0.86 \pm 0.01$ & 4.25 \\
\hline 3 & M 3 & $2.32 \pm 0.03$ & $0.92 \pm 0.03$ & $5.48 \pm 0.20$ & $0.65 \pm 0.12$ & $0.35 \pm 0.03$ & $0.88 \pm 0.07$ & 5.13 \\
\hline 4 & M 4 & $1.85 \pm 0.01$ & $0.04 \pm 0.01$ & $32.80 \pm 0.7$ & $3.17 \pm 0.14$ & $0.42 \pm 0.02$ & $0.64 \pm 0.04$ & 6.15 \\
\hline 5 & M 5 & $3.39 \pm 0.04$ & $0.27 \pm 0.04$ & $25.88 \pm 0.17$ & $2.27 \pm 0.01$ & $0.21 \pm 0.04$ & $0.91 \pm 0.12$ & 7.08 \\
\hline \multirow[t]{4}{*}{6} & M 6 & $2.27 \pm 0.22$ & $0.02 \pm 0.001$ & $27.64 \pm 1.95$ & $2.35 \pm 0.10$ & $0.51 \pm 0.11$ & $0.59 \pm 0.07$ & 5.77 \\
\hline & Min & 1.85 & 0.02 & 5.48 & 0.64 & 0.19 & 0.59 & 4.25 \\
\hline & Max & 3.39 & 0.92 & 32.80 & 3.17 & 0.51 & 0.91 & 7.08 \\
\hline & Mean & 2.44 & 0.33 & 18.70 & 1.73 & 0.33 & 0.77 & 5.62 \\
\hline 7 & Ch 1 & $3.24 \pm 0.10$ & $1.78 \pm 0.04$ & $16.94 \pm 1.62$ & $0.29 \pm 0.08$ & $0.21 \pm 0.001$ & $0.44 \pm 0.05$ & 5.98 \\
\hline 8 & Ch 2 & $2.86 \pm 0.10$ & $1.76 \pm 0.10$ & $25.41 \pm 2.83$ & $0.99 \pm 0.30$ & $0.27 \pm 0.04$ & $0.99 \pm 0.04$ & 6.90 \\
\hline 9 & Ch 3 & $2.62 \pm 0.03$ & $1.75 \pm 0.16$ & $18.13 \pm 0.70$ & $0.26 \pm 0.02$ & $0.22 \pm 0.01$ & $0.71 \pm 0.06$ & 5.58 \\
\hline 10 & Ch 4 & $2.65 \pm 0.08$ & $1.91 \pm 0.07$ & $11.19 \pm 0.59$ & $0.24 \pm 0.02$ & $0.19 \pm 0.01$ & $0.63 \pm 0.01$ & 5.63 \\
\hline 11 & Ch 5 & $3.06 \pm 0.32$ & $2.28 \pm 0.03$ & $22.12 \pm 1.34$ & $0.32 \pm 0.07$ & $0.27 \pm 0.01$ & $0.55 \pm 0.18$ & 6.50 \\
\hline \multirow[t]{4}{*}{12} & Ch 6 & $2.45 \pm 0.14$ & $2.03 \pm 0.13$ & $17.98 \pm 2.01$ & $0.36 \pm 0.04$ & $1.00 \pm 0.01$ & $0.61 \pm 0.07$ & 6.47 \\
\hline & Min & 2.45 & 1.75 & 11.19 & 0.24 & 0.19 & 0.44 & 5.58 \\
\hline & Max & 3.24 & 2.28 & 25.41 & 0.99 & 1.00 & 0.99 & 6.90 \\
\hline & Mean & 2.81 & 1.92 & 18.63 & 0.41 & 0.36 & 0.66 & 6.18 \\
\hline
\end{tabular}

$M$ Merlot wines, Ch Chardonnay wines. Wine regions: 1, Gradsko; 2, Gevgelija; 3, Demir Kapija; 4, Kavadarci; 5, Negotino; 6, Skopje

concentration levels with the mixed standard solution of acids. The spiked recoveries were calculated by following equation: recovery $(\%)=($ found concentration in spiked sample/original concentration in the sample) $\times 100 \%$. The analysis of the spiked red and white wine samples led to calculated recoveries ranging between 95.66 and $108 \%$ for the first concentration level, 94.93 to $103.4 \%$ for the second concentration level, and 97.21 to $100.8 \%$ for the third concentration addition (Table 3). Theoretically, the scope for good recovery value between 90 and $110 \%$ is a confirmation of the validity of the obtained results for the developed method. In addition, obtained recovery values confirmed the accuracy of the method and its suitability for determination of targeted organic acids in white and red wine samples.

\section{Repeatability and Reproducibility}

Repeatability parameter was checked with 6 repetitions in 1 day, while reproducibility was checked with 3 repetitions in 5 consecutive days, both performed on a real white $(\mathrm{Ch} 4)$ and red wine (M2) samples. Concentrations of the analytes were calculated from their corresponding calibration curves. Values for the relative standard deviation of determined concentrations were as follows: for repeatability, ranging from 2.53 to $7.19 \%$ for white wine and 1.96 to $9.5 \%$ for red wine, and for reproducibility, 2.08 to $12.69 \%$ for white wine and 5.21 to $14.77 \%$ for red wine (Table 4 ).

\section{Application of the HPLC-DAD Method to Wine Sample Analysis}

The optimized and validated HPLC-DAD method was applied for determination of organic acids in Macedonian wines: white Chardonnay and red Merlot wines, produced from grapes cultivated in different wine regions in Macedonia. Table 5 summarizes the concentration of individual organic acids in the wines determined by HPLC.

In total, six acids were determined in the wines. Organic acids including tartaric, malic, shikimic, lactic, citric, and succinic were detected in all analyzed wines since they are naturally present in wine or they are formed during the fermentation (citric and succinic acid). Among all organic acids, tartaric acid was found in highest concentration in Chardonnay wines, ranging from 2.45 to $3.24 \mathrm{~g} / \mathrm{L}$ (mean $2.81 \mathrm{~g} / \mathrm{L}$ ). Merlot wines contained tartaric acid in range of 1.85 to $3.39 \mathrm{~g} / \mathrm{L}$ (mean $2.44 \mathrm{~g} / \mathrm{L}$ ). In fact, tartaric acid represents about $50 \%$ of the total acids in wine. It is synthesized in grapes and it is extracted into the wine during the maceration. During the fermentation and aging process, its concentration decreases as a result of formation of tartrates, mainly potassium hydrogen tartrates, which precipitate at the bottom of the tanks and afterwards, are removed from the wine by filtration.

The content of malic acid is usually highest at the beginning of the alcoholic fermentation and afterwards, it converts into lactic acid, spontaneously or in a presence of malolactic 
Observations (axes PC1 and PC2: $62.56 \%$ )
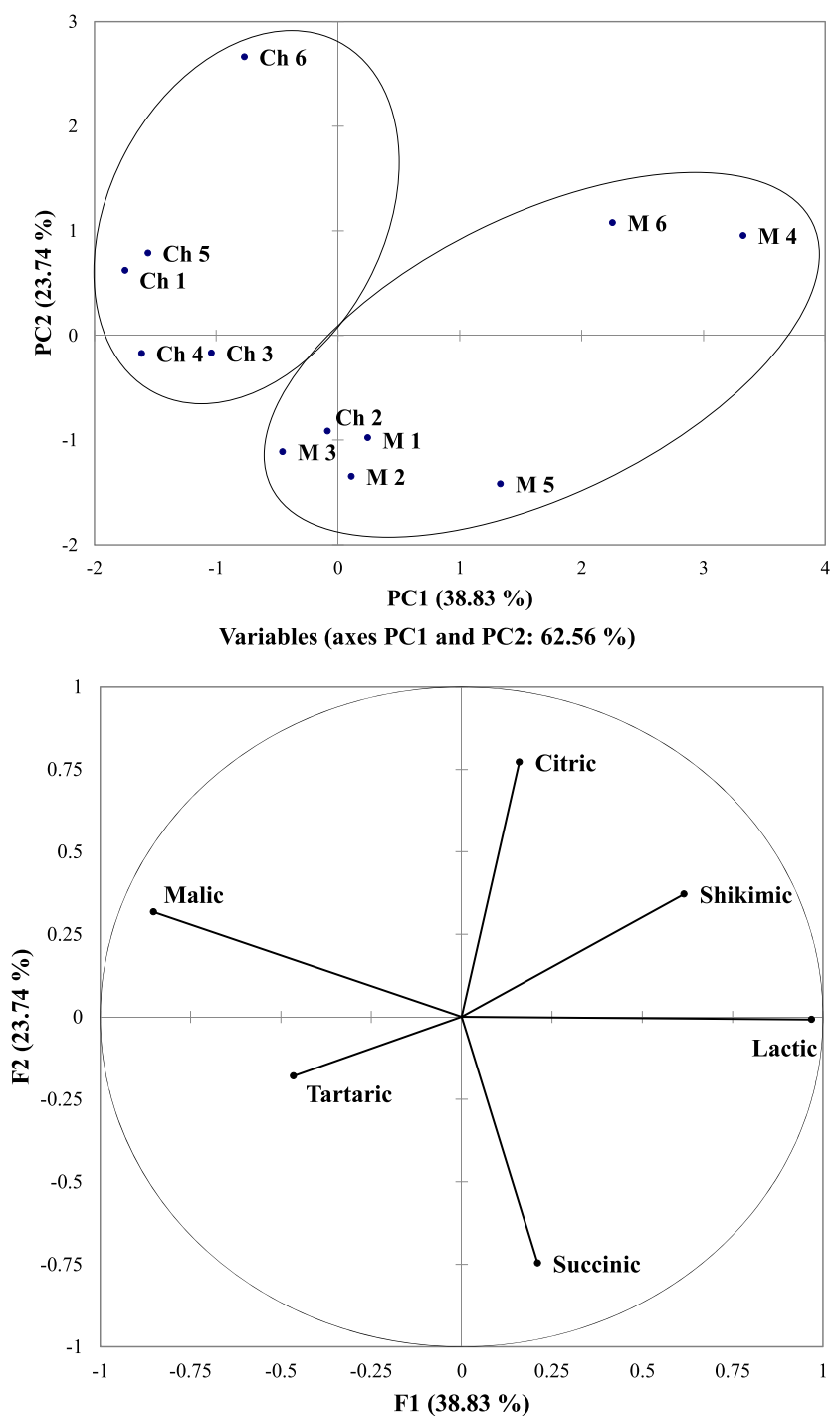

Fig. 3 a Eigenvector projection of wine samples in the space defined for the two first principal components. b PCA loadings of organic acids in wine samples

bacteria, during the malolactic fermentation. During this process, the content of malic acid decreases and the content of lactic acid increases in wine (Davis et al. 1988). In fact, all red wines go through malolactic fermentation after the initial fermentation is complete, spontaneously or inoculated with bacteria culture. Namely, malolactic fermentation is desired in red wines since it softens the taste and texture, adds complexity, reduces the acidity and characters, and stabilizes wine prior to bottling. In our study, all red wines were inoculated with malolactic bacteria and all of them contained low concentration of malic acid, ranging from 0.02 to $0.92 \mathrm{~g} / \mathrm{L}$ and relatively high concentration of lactic acid (range $0.64-3.17 \mathrm{~g} / \mathrm{L}$ ) meaning that malolactic fermentation was completed in the wines. On the contrary, white wines were not inoculated with malolactic bacteria and therefore contained relatively high content of malic acid (range 1.75-2.28 g/L) and low content of lactic acid $(0.24-0.99 \mathrm{~g} / \mathrm{L})$ confirming that malolactic fermentation did not complete.

The content of citric acid in all wines was lower than $1 \mathrm{~g} / \mathrm{L}$ which is in accordance with regulations (Official Gazette of Republic of N. Macedonia 2010). Usually, this acid is added to wine in order to correct the wine acidity, and therefore, its content should be controlled. In our study, citric acid was not added to the wines and its concentration was in normal ranges, from 0.19 to $0.51 \mathrm{~g} / \mathrm{L}$ in red wines (on average $0.33 \mathrm{~g} / \mathrm{L}$ ) and from 0.19 to $1 \mathrm{~g} / \mathrm{L}$ in white wines (on average $0.36 \mathrm{~g} / \mathrm{L}$ ). In addition, succinic acid, which is a by-product of yeast metabolism during fermentation, with a bitter-salty flavor, was found in low concentrations in all wines (lower than $1 \mathrm{~g} / \mathrm{L}$ ), in a range of 0.59 to $0.91 \mathrm{~g} / \mathrm{L}$ (on average $0.77 \mathrm{~g} / \mathrm{L}$ ) in red wines and 0.44 to $0.99 \mathrm{~g} / \mathrm{L}$ (on average $0.77 \mathrm{~g} / \mathrm{L}$ ) in white wines. Shikimic acid was present in lowest concentration compared with the other acids, as expected, since this acid is also present in the lowest concentration in grapes. Thus, the average value of this acid in red wines was similar $(18.70 \mathrm{mg} /$ L) with those for the white wines $(18.63 \mathrm{mg} / \mathrm{L})$, ranging from 5.48 to $32.80 \mathrm{mg} / \mathrm{L}$ and from 11.19 to $25.41 \mathrm{mg} / \mathrm{L}$, respectively (Table 5).

In general, the sum of all determined organic acids was higher in white wines (mean $6.18 \mathrm{~g} / \mathrm{L}$ ) compared with red wines (mean $5.62 \mathrm{~g} / \mathrm{L}$ ), which was expected since white wines contain higher amount of acidity, necessary for their stabilization. In fact, the organic acid's profile and concentration are important parameters to control the $\mathrm{pH}$ of wine and color stability of red wines since anthocyanins retain their red color at low $\mathrm{pH}$, as well as to ensure balance between acid and sweet taste (Coelho et al. 2018). The obtained results for the organic acids in Macedonian wines in this study were similar to those of previous studies published for Macedonian, Slovenian, Croatian, and Greek white and red wines (Tašev et al. 2016; Lopez et al. 1996; Mihaljević Žulj et al. 2015; Zotou et al. 2004) and Port wines (Esteves et al. 2004), as well as Brazilian wines (Peres et al. 2009) and Chile's wines (Tessini et al. 2009).

\section{Principal Component Analysis}

Principal component analysis (PCA) was applied using the dataset of individual organic acids obtained from the HPLCDAD analysis. PCA was used to explore the effect of grape variable vs. geographic wine area based on the acid profile of the analyzed wines. The first two principal components, PC1 and $\mathrm{PC} 2$, accounted for $62.56 \%$ of the total variance $(38.83 \%$ for $\mathrm{PC} 1$ and $23.74 \%$ for $\mathrm{PC} 2$ ), thus explaining a significant information in the dataset. The projection of the wine samples on the first two principal components showed separation mainly into two groups, according to the variety (Fig. 3a): Merlot wines were separated from the Chardonnay wines. 
Merlot wines were mainly located in the positive part of $\mathrm{PC} 1$ (only one samples, M3 was located in the negative part of PC1). Chardonnay wines were grouped in the negative part of PC1. Within the sub-groups of wine, separation according to the geographical wine area was not observed.

The principal components responsible for the differences in the acid composition of the wines produced were determined and presented in the scatter plot in Fig. 3b. The responsible components for the separation of Chardonnay wines were tartaric and malic acids which prevailed in the negative part of the first principal component, while lactic acid was characteristic for the Merlot wines. In general, separation of the wines was performed according to the varietal characteristics.

\section{Conclusion}

This study presents a simple and fast analytical HPLC method for analysis and quantification of the major organic acids (tartaric, malic, shikimic, lactic, citric, and succinic) in red and white wines in a simple 12-min run. The sample preparation applied was very simple and fast (dilution and filtration), and separation of the analytes was performed with an isocratic elution with a simple mobile phase (aqueous solution of $\mathrm{H}_{3} \mathrm{PO}_{4}$ ). The values obtained for the validation parameters were considered acceptable for the intended purpose. The methodology was considered reliable for characterization of red and white wines, dry and sweet. The profile obtained for the organic acids in the wine samples studied showed similar content to those found in other wines from various wine regions in the world.

Funding Information This work was financially supported by following projects: "Chemical characterization of wine, alcoholic beverages, and food by instrumental techniques" provided by Research Fund of the University "Goce Delčev" - Štip, Republic of N. Macedonia and "Dynamic monitoring of ethyl carbamate and its precursors synthesis during wine production and developing a control strategy" provided by the Macedonian Ministry of Education and Science.

\section{Compliance with Ethical Standards}

Conflict of Interest The authors declare that they have no conflict of interest.

Ethical Approval This article does not contain any studies with animals.

Informed Consent It was obtained from all individual participants included in the study.

\section{References}

Castiñeira A, Peña RM, Herrero C, García-Martín S (2002) Analysis of organic acids in wine by capillary electrophoresis with direct UV detection. J Food Compos Anal 15:319-331. https://doi.org/10. 1006/jfca.2002.1056
Coelho EM, Carla Padilha CVS, Miskinis GA, de Sá AGB, Pereira GE, Azevêdo LC, Lima MS (2018) Simultaneous analysis of sugars and organic acids in wine and grape juices by HPLC: method validation and characterization of products from Northeast Brazil. J Food Compos Anal 66:160-167. https://doi.org/10. 1016/j.jfca.2017.12.017

Davis CR, Wibowo D, Fleet GH, Lee TH (1988) Properties of wine lactic acid bacteria: their potential oenological significance. Am J Enol Vitic 39:137-142

Esteves VI, Lima SSF, Lima DLD, Duarte AC (2004) Using capillary electrophoresis for the determination of organic acids in port wine. Anal Chim Acta 513:163-167. https://doi.org/10.1016/j.aca.2003. 12.036

Ivanova-Petropulos V, Naceva Z, Sándor V, Makszin L, DeutschNagy L, Berkics B, Stafilov T, Kilár F (2018) Fast determination of lactic, succinic, malic, tartaric, shikimic, and citric acids in red Vranec wines by CZE-ESI-QTOF-MS. Electrophoresis 39:1597-1605. https://doi.org/10.1002/elps. 201700492

Kordiš-Krapež M, Abram V, Kač M, Ferjančić S (2001) Determination of organic acids in white wines by RP-HPLC. Food Technol Biotechnol 39:93-99 UDC 661.73:663.2:543.844

Lelova Z, Ivanova-Petropulos V, Masár M, Lisjak K, Bodor R (2018) Optimization and validation of a new capillary electrophoresis method with conductivity detection for determination of small anions in red wines. Food Anal Methods 11:1457-1466. https://doi.org/10. 1007/s12161-017-1117-6

Lopez EF, Gomez EF (1996) Simultaneous determination of the major organic acids, sugars, glycerol, and ethanol by HPLC in Grape Musts and White Wines. J Chromatogr Sci 34(5):254-257

Mato I, Suárez-Luque S, Huidobro JF (2007) Simple determination of main organic acids in grape juice and wine by using capillary zone electrophoresis with direct UV detection. Food Chem 102:104-112. https://doi.org/10.1016/j.foodchem.2006. 05.002

Mihaljević Žulj M, Puhelek I, Jagatić Korenika AM, Maslov Bandić L, Pavlešić T, Jeromel A (2015) Organic acid composition in Croatian predicate wines. Agric Conspec Sci 80:113-117

Official Gazette of Republic of N. Macedonia, No. 50, 2010

Pereira V, Câmara JS, Cacho J, Marques JC (2010) HPLC-DAD methodology for the quantification of organic acids, furans and polyphenols by direct injection of wine samples. J Sep Sci 33:1204-1215. https://doi.org/10.1002/jssc.200900784

Peres RG, Moraes EP, Micke GA, Tonin FG, Tavares MFM, RodriguezAmaya DB (2009) Rapid method for the determination of organic acids in wine by capillary electrophoresis with indirect UV detection. Food Control 20:548-552. https://doi.org/10.1016/j.foodcont. 2008.08.004

Regmi U, Palma M, Barroso CG (2012) Direct determination of organic acids in wine and wine-derived products by Fourier transform infrared (FT-IR) spectroscopy and chemometric techniques. Anal Chim Acta 732:137-144. https://doi.org/10.1016/j.aca.2011.11. 009

Saavedra L, Barbas C (2003) Validated capillary electrophoresis method for small-anions measurement in wines. Electrophoresis 24:22352243. https://doi.org/10.1002/elps.200305415

Schneider A, Gerbi V, Redoglia M (1987) A rapid HPLC method for separation and determination of major organic acids in grape musts and wines. Am J Enol Vitic 38:151-155

Silva FLN, Schmidt EM, Messias CL, Eberlin MN, Sawaya ACHF (2015) Quantitation of organic acids in wine and grapes by direct infusion electrospray ionization mass spectrometry. Anal Methods 7:53-62. https://doi.org/10.1039/ c4ay00114a

Tašev K, Stefova M, Ivanova-Petropulos V (2016) HPLC method validation and application for organic acid analysis in wine after solid- 
phase extraction. Maced J Chem Chem Eng 35:225-233. https://oi. org/10.20450/mjcce.2016.1073

Tessini C, Mardones C, Rivas L, von Baer D (2009) Measurement uncertainty of shikimic acid in red wines produced in Chile. Accred Qual Assur 14:381-387. https://doi.org/10.1007/s00769009-0543-6

Tusseau D, Benoit C (1987) Routine high-performance liquid chromatographic determination of carboxylic acids in wines and champagne. J Chromatogr A 395:323-333. https://doi.org/10.1016/S00219673(01)94121-4
Zotou A, Loukou Z, Karava O (2004) Method development for the determination of seven organic acids in Wines by Reversed-Phase High Performance Liquid Chromatography. Chromatographia 60(1-2):39-44

Publisher's Note Springer Nature remains neutral with regard to jurisdictional claims in published maps and institutional affiliations. 